\title{
Religiosity and Entrepreneurship Behaviours
}

\author{
Dogan Gursoy \\ School of Hospitality Business Management \\ College of Business \\ Washington State University \\ Pullman, Washington, USA \\ School of Tourism and Hospitality \\ University of Johannesburg \\ Johannesburg, South Africa \\ Email: dgursoy@wsu.edu \\ Levent Altinay \\ Professor of Strategy and Entrepreneurship \\ Research Area Leader \\ Faculty of Business, \\ Oxford Brookes University, \\ Oxford, OX3 0BP,UK \\ and
}

Ainur Kenebayeva

Management \& Business Department, University of International Business

Almaty, Kazakhstan 


\title{
Religiosity and Entrepreneurship Behaviours
}

\begin{abstract}
This study investigates the impacts of entrepreneurs' religiosity on their values and on the relationship between their values and entrepreneurial behaviours by examining the differences between practicing Muslim entrepreneurs and non-practicing Muslim entrepreneurs. Relationships between values and religiosity are examined within an integrative framework of Schwartz's value theory. Findings suggest that religion plays a critical role in shaping individuals values and their entrepreneurial behaviours. Practicing Muslim entrepreneurs have more respect for, commitment to and acceptance of the religious and traditional customs and ideas compared with those non-practicing Muslim entrepreneurs. On the other hand, non-practicing Muslim entrepreneurs have more independent thoughts and actions when it comes to choosing, creating and exploring compared with those practicing Muslim entrepreneurs. Furthermore, non-practicing Muslim entrepreneurs are more likely to seek for worldly pleasures and sensuous gratification compared with those practicing Muslim entrepreneurs.
\end{abstract}

Keywords: Entrepreneurship; religion; values; innovation; risk taking; Muslim entrepreneurs. 


\section{Religiosity and Entrepreneurship Behaviour in Hospitality}

\section{Introduction}

Religion is a treasury of the most sacred and precious values of society. Religion, being an integral and inseparable part of individual's life, significantly influences the society through shaping human behaviours (Nwankwo and Gbadamosi, 2013). As a collection of cultural as well as spiritual systems of worldviews, believes, values and norms, religion is an essential component of most people's lifestyle (Podgornyi, 2012). Individuals, in particular believers, transform religious values to their various activities including consumption behaviours, business practices as well as working environment (Griebel, Park \& Neubert, 2014, Miller \& Timothy, 2010; Byrne, Morton and Dahling, 2011).

While a small number of studies have examined the influence of values and religion in the field of hospitality and tourism, most of them were focused mainly on the influence of religion on consumers' behaviours and on host community-guest relationships. For example, Eid and El-Gohari (2015) investigated the moderating effect of Islamic religiosity on the relationship between Muslim customer perceived value (MCPV) and Muslim customer satisfaction. Their findings reinforced the importance of religiosity in understanding Muslim customer satisfaction and behaviours. Tavakoli and Mura (2015) also explored Iranian female tourists' patterns of behaviour travelling in Second Life. Their findings showed that in virtual tourist spaces, participants reject 'subordinated' gender-based stereotypes concerning Muslim women's bodily representations in Iran. In addition, investigating the influence of religion on guest and host community relationships, Kirillova, Gilmetdinava and Lehto (2014) explored how religion is involved in constructing hosts' understanding of hospitality and hospitable behaviours in private, public, and commercial settings. Their findings revealed that interpretation of hospitality and hospitable behaviours in private and public domains vary according to religious values while commercial hospitality, somewhat influenced by religion, is mostly understood as a money-making venture. Henderson's (2003) study used Malaysia as a case study to illustrate the problems and opportunities that arise when international guests and the Islamic religion come into contact. Zamani-Farahani and Musa (2012) 
explored the influence of Islamic religiosity on the perceived socio-cultural impacts of tourism among residents in two tourist areas in Iran. The results showed that respondents who possessed a high level of Islamic Belief also perceived socio-cultural impacts of tourism positively.

These studies made important contribution to the literature by demonstrating the influence of values and religion on individuals' attitudes and behaviours and also how values and religion shape the relationship between guests and host communities. However, most of these studies investigated the role religion plays in hospitality and tourism utilizing a demand perspective by mainly focusing on how religion can influence consumers' attitudes and behaviours with a few exceptions. Even though most hospitality and tourism offerings are viewed and consumed as experiences that are produced and delivered through a combination of a diverse array of product and service providers (Jiang, Ramkissoon \& Mavondo, 2016;.Middleton et al., 2009), previous literature has neglected to capture the interface between religious values and hospitality service and product providers; in particular hospitality entrepreneurs. This is surprising given that hospitality entrepreneurship stimulates innovation and creativity and thus contributes to the economic, social and environmental development of destinations (Altinay, Sigala \& Waligo, 2016) and the extent values and religion influence entrepreneurs' behaviours could affect the experience of consumers (Altinay \& Altinay, 2008). For example, in their study of Turkish entrepreneurs, Altinay and Altinay (2008) found that Turkish entrepreneurs who practice their religion do not sell pork and alcohol in their restaurants and therefore cannot respond to the needs to consumers who demand pork and alcohol.

Considering the fact that belief in God plays an important role in how guests are treated in Islam, it is surprising that Muslim entrepreneurs' values and how those values can impact their business practices have not received much attention. Therefore, this study aims to examine the influence of hospitality entrepreneurs' level of commitment to religion on their basic values and their entrepreneurial behaviours, and on the relationships between their basic values and entrepreneurial behaviours. More specifically, this study aims to answer the following four research questions:

1. Does Muslim entrepreneurs' level of religiosity influence their basic values? 
2. Are there any differences between the values of Muslim entrepreneurs who are more committed to Islam and who are less committed to Islam?

3. Are there any differences in any of the four dimensions of entrepreneurial behaviors, namely innovation, risk taking, competitiveness and pro-activeness, between Muslim entrepreneurs who are more committed to Islam and those who are less committed to Islam?

4. Does entrepreneurs' level of religiosity influence the relationship between their basic values and their entrepreneurial behaviors, namely innovation, risk taking, competitiveness and proactiveness?

Since this is one of the first studies that examine impact of Islam on entrepreneurial behavior, findings of this study are likely to advance our knowledge on the impact of Islamic values on entrepreneurial behaviors by making two distinct contributions. Firstly, the study offers insights into the interface between religion, Islam, and entrepreneurial behaviours by demonstrating the influence of Muslim entrepreneurs' basic values on their entrepreneurial behaviours, an area neglected by the previous literature. Secondly, the study offers insights into how Muslim entrepreneurs' level of commitment to their religion can influence the relationships between their basic values and their entrepreneurial behaviours.

\section{Religion \& Entrepreneurship}

Religion is a treasury of the most sacred and precious values of society. Being an integral and inseparable part of an individual's life, religion also holds collective influence over society through its shaping of human behaviour. As a collection of cultural as well as spiritual systems of worldviews, beliefs, values and norms, religion is an essential component of people's lifestyles. As a rule, individuals, in particular believers, transfer religious values to their various activities; this includes business practices as well as the working environment (Griebel, Park \& Neubert, 2014, Miller \& Timothy, 2010; Byrne, Morton, \& Dahling, 2011). Such behaviour is common among religious entrepreneurs who are guided by ethical norms defined by religion during the decision making process (Bornstein \& Miller, 2009; 
Fernando, 2005). This applies to both managing a business and establishing leadership styles (Payne, 2010; Lui \& Wilson, 2011; Weaver \& Agle, 2002). Religion can serve as an ideal ethical system that promotes spirituality along with benefaction, thereby leading to positive moral behavior based on clemency, trustworthiness and honesty. Nwankwo and Gbadamosi (2013, p.625) emphasize that believers adhere to these moral principles and act according to these religious values, which are defined as "a synthesizer of entrepreneurial relations" during risk taking, market research, rationalization and positioning.

Since religion shapes and coordinates entrepreneurial behavior, it affects intrinsic motivational goals described by Schwartz (1992) as a system of values integrating 10 dimensions which are categorized as self-focused orientations representing power, achievement, hedonism, stimulation, and self-direction, as well as other-focused intentions including universalism, benevolence, tradition, conformity, and security. Based on the "Five Factor Model" analysis, Roccas et.al (2002) have investigated the correlations of both values and personality traits with religiosity, and emphasized expressive interconnections between values and religion. Further research (e.g., Schwartz \& Huismans, 1995), through the prism of theological, sociological and psychological approaches, has revealed explicit correlations between religious orientation and values where "conformity/tradition" is argued to be mainly correlated with the religious faith of individuals, while less positive associations related to "security" and "benevolence" (Saroglou, Delpierre \& Dernelle, 2004). Inclination to “conformity/tradition" values expresses the importance of customs defined by a religion as well as the acceptance of a certain level of conservatism in actions or during the decision making process. "Security" values relate to uncertainty avoidance and imply social order protection, while benevolence refers to possessing good intention towards others. Findings additionally indicate that religiosity reduces the importance of hedonistic values which is evidenced by the most negative correlation coefficient (Fontaine, Luyten and Corveleyn, 2000). Moreover, “stimulation” and "self-direction" values are less expressively, and yet negatively correlated with religion (Saroglou, Delpierre and Dernelle, 2004). Additionally, religiosity is not associated by a significant meaning attributed to "power" connected to prestige, or "achievement" indicating respectable status in society, and 
“universalism” representing humans' welfare (Schwartz et.al., 2001; Saroglou, Delpierre \& Dernelle, 2004).

Schwartz (2012) has conceptualized the model of value relations expanding on conformity as well as contradiction between 10 value dimensions. According to Schwartz's conceptual model, values are clustered as two bipolar measurements, contrasting "openness to change" versus "conservation" on the one hand, and "self-enhancement" versus "self-transcendence" on the other hand. The first category of bipolar dimensions represents the oppositions between motivational values associated with the challenge oriented, independent action and novelty seeking behavior and values that prioritize the importance of relationships, stability and conservatism. The second category of measurements covers the discrepancy between values that define motivational goals oriented towards competent performance, social predominance and controlling power and values indicating social welfare, tolerance and supportive relationships. As defined by Schwartz (2012), "hedonism" contains a dual characteristic; consequently it can be associated with both "openness to change" and "self-enhancement". "Conformity" along with "tradition" shares the similar system of desirable goals, and is therefore located in a joint sector (See Figure 1). Moreover, Schwartz (2012) has expanded the conceptual framework of value systems and described the relations of values to anxiety that is considered as individuals' perceptions regarding uncertainty (See Figure 1). "Self-enhancement" and "Conservation" dimensions are categorized as anxiety-based values mainly oriented to self-protection, while "openness to change" and "selftranscendence" reflect anxiety-free motives generally focusing on growth and self-expansion.
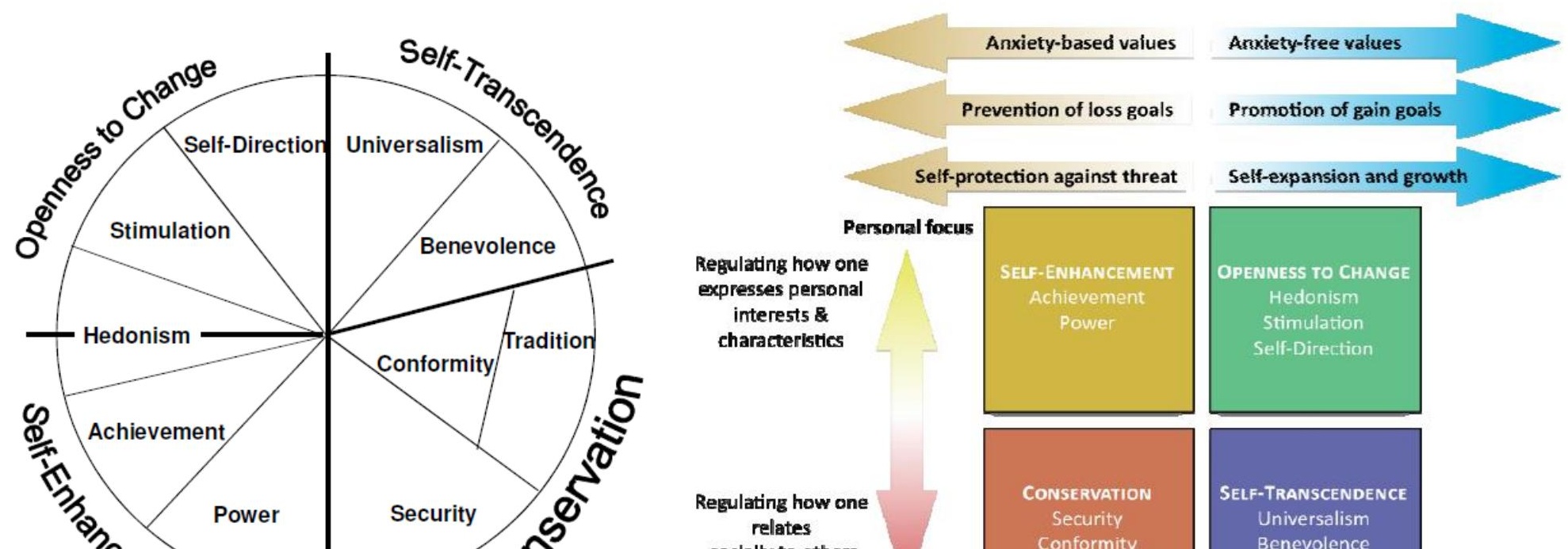
Figure 1. Source: Schwartz, S. H. (2012). An Overview of the Schwartz Theory of Basic Values. Online Readings in Psychology and Culture, 2(1), p. 9).

Studies investigating the relationship between Islam and entrepreneurship has found that Islamic values affect the main aspects of business enterprises such as management (Dyck, 2014; Abuznaid, 2009); organizational ethics, including responsible business conduct (Hassan, 2016; Ismaeel \& Blaim, 2012; Graafland, Mazereeuw \& Yahia, 2006); marketing (Arham, 2010; Elfakhani \& Ahmed, 2013); capital and fund raising (Elfakhani \& Ahmed, 2013). For example, Islam shapes the behaviours of Muslim entrepreneurs by redirecting internal motivational forces from utility maximization, associated with a material reward system, to spiritual gains: assuming the system of benefits and welfare created not only for oneself but also for others (Gümüsay, 2015). Graafland, Mazereeuw and Yahia (2006, p.392) state that "a Muslim businessman should be driven by a socially useful service motive instead of a profit motive". Hoque, Mamun and Mamun (2014) identify traits of Islamic entrepreneurs such as honesty, hardworking, truthfulness, patience, morality, strategic thinking, social welfare, etc. which can be considered as the most influential values shaping the behaviour of individuals at the micro-level. However, depending on the individual level of spirituality, Muslim believers may possess different levels of devotion and ethical recognition (Ismaeel \& Blaim, 2012). Therefore, in order to provide clear insights into the interrelation between religion and entrepreneurship, Altinay (2008) suggests demarcating two concepts such as "practising Muslim believers" and "non-practising Muslims". The distinction is important for research because these two categories of entrepreneurs demonstrate different models of entrepreneurial behaviour according to the different levels of religiosity, and depending on the extent to which entrepreneurs apply religious values to everyday life. For example, Altinay (ibid), in the case of 
ethnic Turkish Muslims, argues that entrepreneurs with a weak religious bias are more inclined to deviate from the common norms proscribed by Islam (such as taking interest-based financial loans, selling alcohol and pork) in order to more easily exploit opportunities in long-standing markets; this is instead of seeking new opportunities in a niche market (Halal and Muslim-friendly) which in turn may require additional monetary as well as non-monetary costs, and likely needs an innovative approach to entrepreneurial exploitation.

As suggested by the preceding discussion, entrepreneurs' religiosity is likely to affect their values, attitudes and behaviours. This study aims to understand the impact of level of commitment to religion on values and entrepreneurial behaviour by drawing upon human values across power, achievement, hedonism, stimulation, self-direction, universalism, benevolence, tradition, conformity, and security dimensions. In particular, this study will offer new insights into our understanding of the impacts of religiosity on the relationship between these values and entrepreneurial behaviours namely innovation, risk taking, competitiveness and pro-activeness.

\section{Research Methodology}

Data for this study were collected from the owners of small and medium enterprises (SME) who were members of one of the SME associations located in Turkey. The SME association has around 600 members. Even though the association is open to all SME owners, most of the members of this SME association are Muslim SME owners. Considering the fact that Islam is the main religion in Turkey, this is not very surprising. One of the authors of this study has been serving as a consultant to the SME association for over 10 years and, therefore, has very close relationships with the SME association. Utilizing the personal contacts in the SME association, permission was received from the SME association's board of directors to conduct a survey. A cross-sectional, self-administered survey instrument was used to gather data during the monthly meeting of the SME association. Right before the monthly meeting, the self-administered survey was distributed to the members of the SME association. Completed surveys were collected right after the meeting. A total of 330 completed surveys were 
received. However, only 300 of the responses from entrepreneurs were used in this study because either the response was incomplete or the respondent did not answer the question that measured the respondent's religious orientation; whether the respondent is a practicing Muslim entrepreneur or a non-practicing Muslim entrepreneur.

Respondents' motivationally distinct value orientations were measured utilizing the basic human values scale developed by Swartz $(1992,1996)$. A total of 10 dimensions of basic human values were measured by 57 questions included in the original Swartz Value Scale (SVS) (Schwartz, 1992, 1996). These 10 basic values included Power, Achievement, Hedonism, Stimulation, Self-Direction, Universalism, Benevolence, Tradition, Conformity, and Security. Scores on these 10 value scales have been shown to load on two dimensions: Conservation versus Openness to Change and Self-Transcendence versus Self-Enhancement (Schwartz, 1992). Since the data were collected from entrepreneurs in Turkey, the instrument was back translated to Turkish by a native speaker of Turkish. The participants were asked to rate the importance they would give to the 57 value items as life-guiding principles on a 9-point rating scale ranging from -1 (opposed to my principles), 0 (not important), 3 (important), to 7 (of supreme importance). After collecting the data, a summated scale was generated for each value dimension utilizing a priori loading approach for each dimension. These summated scales were used in the analysis.

Respondents risk taking behaviours (if there is a possibility of failure in a new endeavour, you should not take a chance (this was reverse coded); Taking risk is a prerequisite for success), competitiveness behaviours (I like competing against others; competitive behaviours should be encouraged) and pro-activeness behaviours (if you work hard enough, nothing is impossible; if you work hard, you will succeed no matter what) were measured using two items. Innovation behaviour was measured by a single questions (creativeness and innovation is a must for success). Individuals' level of commitment to the Islamic religion was also measured by a single questions; how would you describe your religious orientation. Responses were categorized into two groups based on their responses: 1) I strictly follow the guidelines of Islam and 2) I believe in Good but I do not practice. 


\section{Data Analysis}

Data were analysed utilizing a two-step process. First, a series of t-test were conducted to examine the influence of entrepreneurs' level of commitment to religion on 10 dimensions of basic human values, and entrepreneurs risk taking, competitiveness, pro-activeness and innovation behaviours. In the second step, a series of regression model were tested in order to identify the influence of individuals' level of commitment to religion on the relationships between values and entrepreneurial behaviours. First, all value dimensions were regressed on each entrepreneurial behaviour. Afterwards, a separate multiple regression was run for practicing Muslim entrepreneurs group and non-practicing Muslim entrepreneurs group; all value dimensions were regressed on each entrepreneurial behaviour for each group.

\section{RESULTS AND DISCUSSION}

Findings of the t-tests indicated significant differences in three values of individuals who practice religion and those who believe in God but do not practice religion as presented in Table 1. Significant differences between traditional values of practicing Muslim entrepreneurs $(\mathrm{M}=4.90, \mathrm{SD}=1.23)$ and traditional values of non-practicing Muslim entrepreneurs $(\mathrm{M}=4.26, \mathrm{SD}=1.37)$ were found at the $\mathrm{p}<.05$ level. This finding suggest that practicing Muslim entrepreneurs have more respect for, commitment to and acceptance of religious and traditional customs and ideas compared with those non-practicing Muslim entrepreneurs. This finding is not surprising considering the fact that individuals who practice a religion are more likely to be committed to that religion and accept the values and norms promoted by that religion as they are compared to individuals who does not practice (Roccas \& Schwartz, 1997; Schwartz, Melech, Lehmann, Burgess, Harris, and Owens, 2001). As suggested by previous studies, believers adhere to the norms and principles promoted by the religion and act accordingly (Nwankwo \& Gbadamosi, 2013). For example, among Israeli Jewish students, subjective religiosity was found to be most positively correlated with tradition values (Schwartz et al., 2001).

\section{INSERT TABLE 1 ABOUT HERE}


Findings also indicated significant differences between self-direction values of practicing Muslim entrepreneurs $(\mathrm{M}=5.40, \mathrm{SD}=0.99)$ and the self-direction values of non-practicing Muslim entrepreneurs $(\mathrm{M}=5.64, \mathrm{SD}=0.94)$ at the $\mathrm{p}<.05$ level. Non-practicing Muslim entrepreneurs were found to have more independent thoughts and actions when it comes to choosing, creating and exploring compared with those practicing Muslim entrepreneurs. Considering the fact that religion provides a sacred basis for prevailing norms and social structure, practicing Muslim entrepreneurs are more likely to accept the social order and norms while non-practicing Muslim entrepreneur are more likely to question the social order and norms, which is likely to result in non-practicing Muslim entrepreneurs having higher self-direction values. As suggested by Schwartz and Huismans (1995), religiosity reflects, at least in part, the intensity of the need to reduce uncertainty. Since acceptance of norms is likely to reduce the level of uncertainty in one's life, it is also likely to decrease the level of self-direction and make them adhere to the social order and norms (Nwankwo \& Gbadamosi, 2013).

Findings further indicated significant differences between hedonism values of practicing Muslim entrepreneurs $(\mathrm{M}=4.16, \mathrm{SD}=1.65)$ and hedonism values of those non-practicing Muslim entrepreneurs $(\mathrm{M}=4.60, \mathrm{SD}=1.46)$ at the $\mathrm{p}<.05$ level. This finding suggest that non-practicing Muslim entrepreneurs are more likely to seek for worldly pleasures and sensuous gratification compared with those practicing Muslim entrepreneurs. Higher level of religiosity is likely to reduce the importance of hedonistic values by promoting respect and humility (Fontaine, Luyten and Corveleyn, 2000) while individuals who are not religious are likely to seek happiness through the pursuit of material goods and worldly pleasures (Schwartz and Huismans, 1995). Individuals who pursue material goods and worldly pleasures tend to place a great emphasis on the satisfaction in life and happiness derived by the possession of material goods. This lifestyle, to a certain extent, can have significant impact on how they run their businesses. Since their main goal is likely to be acquisition of wealth in order to pursue their goals, they may not pay much attention to social and environmental issues, which may have significant impact on the communities where these SME operate. 
Examination of the influence of individuals' level of commitment to religion on entrepreneurial behaviours indicated that individuals level of commitment to religion only effects their competitiveness behaviours. Non-practicing Muslim entrepreneurs $(\mathrm{M}=3.87, \mathrm{SD}=0.69)$ were found to be more competitive compared with practicing Muslim entrepreneurs $(\mathrm{M}=3.68, \mathrm{SD}=0.71)$ at the $\mathrm{p}<.05$ level. This finding clearly suggest that religiosity not only affects personal values but also affects the way entrepreneurs operate their businesses (Dodd \& Seaman, 1998; Dyck, 2014). Previous studies report that entrepreneurs' religiosity can have significant impact on the management (Dyck, 2014; Abuznaid, 2009) and marketing practices (Arham, 2010; Elfakhani \& Ahmed, 2013). Considering the fact that Islam shapes the behaviours of Muslim entrepreneurs by emphasizing spiritual gains and creation of benefits and welfare not only for oneself but also for others (Gumusay, 2015), it is not surprising to see that practicing Muslim entrepreneurs tend to be less competitive compared to non-practicing Muslim entrepreneurs. This finding may suggest that practicing Muslim entrepreneurs may have stronger emotional ties with their community, and, therefore, they may exhibit more socially responsible daily behaviours for the good of their community. Since this study did not test this relationship, it is strongly recommended that future studies examine the relationships between religiosity and corporate social responsibility behaviours of SME.

\section{Impacts of religiosity on the relationship between entrepreneurs' values and their innovation behaviour}

Table 2 presents the significant relationships between values and entrepreneurs' innovation behaviours for the whole sample and the significant relationships between values and entrepreneurs' innovation behaviours for practicing Muslim entrepreneurs and non-practicing Muslim entrepreneurs. As presented in Table 2 , only two value dimensions, conformity $(b=.18, t=2.30, p<.05)$ and self-direction ( $b=.73, t=8.38, p<.05)$, out of 10 value dimensions were found to be significant determinants of entrepreneurs' innovation behaviours regardless of their religious orientation. While the self-direction value had a large effect on entrepreneurs' innovation behaviours, the conformity dimension was found to have a relatively small effect on entrepreneurs' innovation behaviours. The large effect of self-direction 
value may be explained by the fact that both practicing and non-practicing Muslim entrepreneurs have strong self-direction values for different reasons. While non-practicing Muslin entrepreneurs are likely to have more independent thoughts and actions when it comes to choosing, creating and exploring compared with those practicing Muslim entrepreneurs, practicing Muslim entrepreneurs are likely to form their selfdirection values based on the social order and norms. Both approaches are likely to result in strong selfdirection values for both groups, which is likely to increase their innovation behaviour for the purpose of personal gains and/or for the good of the society.

\section{INSERT TABLE 2 ABOUT HERE}

Results also suggested that only self-direction dimension $(b=-.73, t=8.38, p<.05)$ among 10 value dimensions had a significant impact on practicing Muslim entrepreneurs' innovation behaviours while three value dimensions, conformity $(b=-.21, t=2.25, p<.05)$ self-direction $(b=.70, t=6.92, p<$ $.05)$ and achievement $(b=.20, t=2.01, p<.05)$ were found to be significant determinants of nonpracticing Muslim entrepreneurs' innovation behaviours. This finding clearly suggest that while selfdirection is a significant determinant of innovation behaviours for all Muslim entrepreneurs' innovation behaviours, conformity and achievement are critical determinants of innovation behaviours for only nonpracticing Muslim entrepreneurs. Since the conformity values of non-practicing Muslim entrepreneurs tend to be lower than conformity values of practicing Muslim entrepreneurs, non-practicing Muslim entrepreneurs need to place special emphasis on conforming to the norms and expectations if they want to be innovative in a Muslim society. This may sound contradictory to the fundamental foundation of the concept of innovation but in a Muslim society, motivation to become an entrepreneur is expected to be based on pure intentions of helping others since Islam requires entrepreneurs to get involved in socially useful entrepreneurial activities and follow the rules set by the holy book while running a business (Hassan, 2016)

\section{Impacts of religiosity on the relationship between entrepreneurs' values and their risk taking}


As presented in Table 3, only three value dimensions, benevolence $(b=.18, t=2.24, p<.05)$, stimulation $(b=.13, t=3.46, p<.05)$ and power $(b=-.18, t=-3.69, p<.05)$, out of 10 value dimensions were found to be significant determinants of entrepreneurs' risk taking behaviours regardless of their religious orientation. While the impact of benevolence $(b=.18, t=2.24, p<.05)$ and stimulation $(b=.13$, $t=3.46, p<.05)$ were positive on Muslim entrepreneurs' risk taking behaviours, power $(b=-.18, t=$ $3.69, p<.05)$ was found have negative impact on Muslim entrepreneurs' risk taking behaviours. However, all of three were found to have relatively small effects on Muslim entrepreneurs' risk taking behaviours. The small effect of benevolence may be explained by the fact that it represents other-focused intentions. Furthermore, simulation values are found to be less expressively correlated with religion in other studies (Saroglou, Delpierre and Dernelle, 2004). Since one of the main focus of entrepreneurs is personal gains, other-focused intentions and values that are less expressively correlated with religion may play a smaller role in their risk taking behaviour. Negative relationship between power values and risk taking behaviour may be due to the fact that Muslim entrepreneurs may not want to risk their "power" in their community which is strongly connected to prestige, or achievement indicating respectable status in society (Schwartz et.al., 2001; Saroglou, Delpierre \& Dernelle, 2004). In order to preserve their power, they may not be willing to take risks that may jeopardize their status in their community.

\section{INSERT TABLE 3 ABOUT HERE}

Results suggested that only power $(b=-.21, t=2.00, p<.05)$ among 10 value dimensions had a significant impact on practicing Muslim entrepreneurs' risk taking behaviours while three value dimensions, tradition $(b=-.14, t=-2.48, p<.05)$, benevolence $(b=.27, t=2.84, p<.05)$ and stimulation $(b=.15, t=3.01, p<.05)$ were found to be significant determinants of non- practicing Muslim entrepreneurs' risk taking behaviours. This finding clearly suggests that power decreases practicing Muslim entrepreneurs' risk taking behaviours. Power values in this study refer to individuals' social status and prestige in a society, their control or dominance over people and resources. Power values emphasize attaining or preserving a dominant position within the social system. (Schwartz, 2006). Since practicing Muslim entrepreneurs tend to be more conservative and place a strong emphasis on preservation of status- 
quo, as their social status within a community increases, they may be less willing to take risks that may endanger their status within that community. Furthermore, as stated by Graafland, Mazereeuw \& Yahia (2006, p.392) "a Muslim businessman should be driven by a service motive instead of a profit motive.” Since businesses take risks, hoping that increased risk will result in higher returns, risk taking behaviour goes against the main premise of practicing Muslim entrepreneurs' motivations especially for practicing Muslim entrepreneurs with high power values.

Findings also suggest that tradition is likely to have a negative effect on non-practicing Muslim entrepreneurs risk taking behaviours. This finding might be due to the fact that traditional values require individuals' subordination to more abstract objects and ideas such as religious and cultural customs and ideas (Schwartz, 2006). Since these values demand individuals' unconditional acceptance of the traditional values, they are likely to have significant impact on non-practicing Muslim entrepreneurs risk taking behaviours. As non-practicing Muslim entrepreneurs' tradition values increase, their risk taking behaviours are likely to decrease in order to conform to the tradition values.

Benevolence and stimulation are found to significantly increase risk taking behaviours of nonpracticing Muslim entrepreneurs. Benevolence values reflect the central role of the family in a person's cooperative relations, social connections, and development of all further values. On the other hand, hedonism values refers to pleasure and sensuous gratification for oneself. While these two may seem significantly different, both values provide internalized motivational bases for these behaviours. These values emphasize welfare of and providing benefits for close social group and/or for self. Since risk taking behaviour can result in higher returns and the non-practicing Muslim entrepreneurs are not bound by the conservative rules that unable practicing Muslim entrepreneurs to take risk for higher returns, nonpracticing Muslim entrepreneurs are more likely to take risks to improve self’s and/or close social groups welfare compared with practicing Muslim entrepreneurs. Therefore, higher the benevolence and hedonism values of non-practicing Muslim entrepreneurs, higher the risk taking behaviour. 
Impacts of religiosity on the relationship between entrepreneurs' values and their competitiveness behaviour

Only three value dimensions, self-direction $(b=.17, t=2.83, p<.05)$, achievement $(b=.19, t=$ $3.50, p<.05)$ and power $(b=-.09, t=-2.132, p<.05)$, out of 10 value dimensions were found to be significant determinants of entrepreneurs' competitiveness behaviours regardless of their religious orientation. While the impact of self-direction $(b=.17, t=2.83, p<.05)$ and achievement $(b=.19, t=$ $3.50, p<.05)$ were positive on Muslim entrepreneurs' competitiveness behaviours, power $(b=-.09, t=$ 2.132, $p<.05$ ) was found have a negative impact on all Muslim entrepreneurs' competitiveness behaviours. However, all three were found to have relatively small effect on Muslim entrepreneurs' competitiveness behaviours.

\section{INSERT TABLE 4 ABOUT HERE}

Results suggested that three value dimensions, universalism $(b=.31, t=2.54, p<.05)$, selfdirection $(b=.26, t=2.52 p<.05)$ and security $(b=-.27, t=-2.026, p<.05)$ out of 10 value dimensions had significant impacts on practicing Muslim entrepreneurs' competitiveness behaviours while two value dimensions, achievement $(b=.18, t=2.54, p<.05)$ and power $(b=-.11, t=-2.24, p<.05)$ were found to be significant determinants of non-practicing Muslim entrepreneurs' competitiveness behaviours. While security $(b=-.27, t=-2.026, p<.05)$ was found to have a negative effect on practicing Muslim entrepreneurs competitiveness behaviours, power $(b=-.11, t=-2.24, p<.05)$ was found to have a negative effect on non-practicing Muslim entrepreneurs competitiveness behaviours. Findings also suggested that universalism and self-direction had moderate positive effects on competitiveness behaviours of practicing Muslim entrepreneurs, achievement was found to have a small positive effect on competitiveness behaviours of non-practicing Muslim entrepreneurs.

These findings can be explained by the fact that while practicing Muslim entrepreneurs place more emphasis on the well-being of the society, social norms, traditions and preserving the status-quo, nonpracticing Muslim entrepreneurs tend to place more emphasis on benefits and gains for the self, personal gains and profits and getting ahead. As a result, non-practicing Muslim entrepreneurs with higher 
achievement and power values tend to be more competitive because both power and achievement values focus on social esteem. Achievement values emphasize actively demonstrating successful performance in concrete interaction, whereas power values emphasize attaining or preserving a dominant position within the more general social system. On the other hand, practicing Muslim entrepreneurs with higher universalism, self-direction, and security values are likely to be more competitive in order to generate benefits for the society and to improve the well-fare of those around them.

\section{Impacts of entrepreneurs' values on their pro-activeness behaviour}

Examination of the effect sizes for each group of Muslim entrepreneurs indicated that that none of the value dimensions had any significant effect on entrepreneurs' pro-activeness behaviours. Findings further suggest that entrepreneurs' level of religiosity is not likely to influence the relationships between entrepreneurs' values and their pro-activeness behaviours. This finding is not surprising considering the fact that Islam requires individuals to conform to social norms and values. Muslim entrepreneurs are likely to view values that enable them to avoid uncertainty and change as more important compared to values that can result in motivations to follow one's hedonistic desires, encourages questioning, innovation, independent thoughts and actions compared with other entrepreneurs. Since being pro-active may be viewed as "openness to change" and "self-transcendence" which reflect anxiety-free motives generally focusing on growth and self-expansion, Muslim entrepreneurs, regardless of whether they are practicing Muslim or not, may not exhibit pro-active behaviors.

\section{CONCLUSIONS}

Hospitality industry is among the few industries that offer significant business opportunities to individuals with strong drive and entrepreneurial spirit because a large portion of hospitality services are provided by small and medium sized businesses. Even though entrepreneurship and small businesses play a critical role in the delivery of multidimensional hospitality products, which are usually consists of a series of experiences' achieved through a combination of a diverse array of products and services, 
entrepreneurship in hospitality has not received much attention from hospitality scholars (Li, 2008). Most of the studies in hospitality have focused on the importance of small firms in the job creation and regional economic impact and the relationship between firms' sizes, survival, and constraints on firm growth. A small number of studies have also examined entrepreneurial behaviour and activities in hospitality field. However, most of those studies focused on identification of opportunities (Bussell \& Faulkner, 1999; Bussell \& Faulkner, 2004), motivations and how motivations can affect decision making (Keith \& Malcolm, 1997), and the influence of entrepreneurial behaviours of employees on hospitality organizations (Jogaratnam, Tse, \& Olsen, 1999; William \& Tse, 1995).

This study extends our knowledge about entrepreneurial behaviours by specifically examining the impacts of entrepreneurs' level of religiosity on their values and on the relationship between their values and their entrepreneurial behaviours within an integrative framework of Schwartz's value theory. While findings of this study clearly suggest that religion plays a critical role in individuals' everyday life by shaping their values and entrepreneurial behaviours, level of religiosity and its effect on entrepreneurial behaviour has not received much attention from hospitality scholars. One explanation for this might be that religion, especially Islam, is rarely attributed to shaping economic phenomena in hospitality industry. Considering the fact that hospitality in Islam is considered to have three components, host, guest, and the God, and especially belief in God plays important roles in how guests are treated, it is surprising that Muslim entrepreneurs' values and how those values impacts their business practices have not received much attention. Since this is one of the first studies that examine impact of level of Islam religiosity on hospitality entrepreneurship behavior, findings of this study advances our knowledge on the impact of Islamic values on entrepreneurial behaviors.

Previous studies suggest that individuals' religiosity are critical determinants of their values, attitudes and behaviours (Duriez, Fontaine, \& Luyten, 2001; Fontaine, Luyten, P., \& Corveleyn, 2000; Kusdil \& Kagitcibasi, 2000; Roccas, Sagiv, Schwartz, \& Knafo, 2002; Roccas \& Schwartz, 1997; Schwartz \& Huismans, 1995). Findings of this study furthers our understanding of the impact of level of religiosity by providing support for the underlying assumption of this study that Muslim entrepreneurs' 
level of religiosity not only influence their everyday life but also their values that can influence their business practices as well. Entrepreneurs who are more committed to Islam are found to place relatively more importance on values that enable them avoid uncertainty and change and relatively low importance on values that can result in motivations to follow one's hedonistic desires, encourages questioning, innovation, independent thoughts and actions compared with entrepreneurs who are less committed to Islam. Findings further indicate that entrepreneurs' level of religiosity also have significant influences on the magnitude and direction of the relationships between their values and their entrepreneurial behaviours for practicing Muslim entrepreneurs and non-practicing Muslim entrepreneurs. However, it is important to note that not all value dimensions are likely to influence Muslim entrepreneurs' entrepreneurial behaviours. For example, only three of the 10 value dimensions (universalism, self-direction and security) are found to be significant determinants of practicing Muslim entrepreneurs' competitiveness behaviours while two value dimensions, achievement and power are found to be significant determinants of nonpracticing Muslim entrepreneurs' competitiveness behaviours. These findings clearly suggest that level of religiosity not only moderates the relationships between values and entrepreneurship behaviour, but also moderates the level of importance placed on the values. These findings also provide support for the second underlying assumption of this study that Muslim entrepreneurs' level of religiosity influence the relationships between their values and their entrepreneurial behaviours.

Differences in level of religiosity can be viewed as an obstacle or an opportunity to improve the entrepreneurial behaviour in Muslim communities. Some policy makers may see those differences as superficial and may ignore them. They may even believe that practicing Muslim individuals may not even be a good prospective entrepreneurs because of their focus on uncertainty avoidance and resistance to change. However, because of their focus on the well-being of the society, social norms, traditions and preserving the status-quo, practicing Muslim entrepreneurs may represent a unique group of entrepreneurs who highly value their community and preservation of traditional values and norms. Considering the fact that the hospitality industry heavily relies on cultural-heritage resources (Gallarza, Arteaga \& Gil-Saura, 2015), preservation of traditional values and norms are likely to result in better experiences for visitors to 
the area (Tresidder, 2015). Furthermore, these entrepreneurs are likely to care about their business reputation in the community. If they believe that their businesses provide benefits to the local community, they are likely to encourage other businesses to take more socially responsible actions (Cetin \& Walls, 2016). Positive impacts brought by responsible practices are also likely to improve their personal and business reputation (Stylos \& Vassiliadis, 2015). Owning a company with favourable reputation are also likely to reinforce these entrepreneurs' self-respect and self-fulfilment. Furthermore, nurturing entrepreneurs' affections for the local community can help strengthen their sense of social responsibility. These businesses are likely to hire locals for managerial positions because locals are likely to have stronger emotional attachment to their communities, and have stronger identification with the values of the community.

Practicing entrepreneurs might have the advantage of commitment and acceptance of the religious and traditional customs and this might well reflect itself in operational practices. For example, they might not sell alcohol or pork in their outlets. Moreover, in the case of hotels, they might operate their hotels according to the Islamic or halal concept. Such practices, however, might limit their market scope to a very niche market; 'Muslim Customers' only. Moreover, those practicing entrepreneurs might end up selecting and recruiting only those employees who have and demonstrate commitment to the religious and traditional customers. Such a practice could well lead to 'too conservative and traditional vision' hindering creative and innovative thinking in organisations. On the other hand, non-practicing Muslim entrepreneurs have more independent thoughts and actions which could lead to more creativity and innovation in terms of the business practices. They can still preserve and adopt their practices to the Islamic culture and to the expectations of practicing Muslims. However, whilst maintaining this "culture and Islam centric values", they can adopt their practices to the expectations of Non-Muslim and/or to non-practicing Muslim customers. Striking such balance is important for Islamic but secular tourism and hospitality destinations such as Turkey, Egypt and Maldives where millions of tourists are hosted every year.

Although the results of this study help extend our understanding of entrepreneurial behaviours, it is important to consider the findings of this study within their proper perspective. First, the study was 
conducted in one geographic region (i.e., Turkey). Because there are other Muslim entrepreneurs living in other locations and cultures, and the impacts of level of religiosity on entrepreneurial behaviour may vary from religion to religion, additional research is still needed to fully understand the impacts of level of religiosity on entrepreneurial behaviour in different geographic regions, cultures and religions. Another limitation is that data were collected from entrepreneurs who were members of one of one SME association in Turkey. This approach may not guarantee that all entrepreneurs had the possibility of being included in the sample. Therefore, results may not be applicable beyond the sample. Replication of this study in other countries, cultures and religions may be required to confirm the validity of the findings reported in this study. Furthermore, this study did not examine how religiosity may influence entrepreneurs' attitudes and behaviors towards social responsibility. As indicated earlier, level of religiosity may be an important indicator of socially responsible business practices. Future studies should examine the impact of level of religiosity on attitudes and behaviors towards social responsibility practices. 


\section{References}

Abuznaid, S.A. (2009). Business ethics in Islam: the glaring gap in practice. International Journal of Islamic and Middle Eastern Finance and Management, 2(4), 278-288.

Altinay, L. \& Altinay,E. (2008),"Factors influencing business growth: the rise of Turkish entrepreneurship in the UK", International Journal of Entrepreneurial Behaviour \& Research, Vol. 14 Iss 1pp. $24-46$

Altinay, L. \&. Wang, C.L. (2011),"The influence of an entrepreneur's socio-cultural characteristics on the entrepreneurial orientation of small firms", Journal of Small Business and Enterprise Development,

Altinay,L. (2008),"The relationship between an entrepreneur's culture and the entrepreneurial behaviour of the firm", Journal of Small Business and Enterprise Development, Vol. 15 Iss 1 pp. 111 129

Anderson, A.R., Drakopoulou-Dodd, S.L., \& Scott, M.G. (2000). Religion as an environmental influence on enterprise culture. The case of Britain in the 1980s. International Journal of Entrepreneurial Behavior \& Research, 6(1), 5-22.

Arham, M. (2010). Islamic perspectives on marketing. Journal of Islamic Marketing, 1(2), 149164.

Battour, M., \& Ismail, M.N. (2015). Halal tourism: Concepts, practices, challenges and future. Tourism Management Perspectives, doi: 10.1016/j.tmp.2015.12.008

Bornstein, Brian H. and Miller, Monica K., "Does a Judge's Religion Influence Decision Making?" (2009). Court Review: The Journal of the American Judges Association. Paper 300

Bussell, R., \& Faulkner, B. (1999). Movers and Shakers: Chaos makers in tourism development. Tourism Management, 20, 411-423.

Bussell, R., \& Faulkner, B. (2004). Entrepreneurship, chaos and the tourism area lifecycle. Annals of Tourism Research, 8 (1), 1-23.

Byrne,C.J., Morton, D.M., \& Dahling, J.J. (2011). Spirituality, religion, and emotional labor in the workplace. Journal of Management, Spirituality \& Religion, 8 (4), 299-315.

Candland, C. (2001). Faith as social capital: religion and community development in Southern Asia. Policy Sciences, 33(3/4), p. 355-374.

Carswell, P. \& Rolland, D. (2007). Religion and entrepreneurship in New Zealand, Journal of Enterprising Communities: People and Places in the Global Economy, 1(2), 162-174.

Cetin, G., \& Walls, A. (2016). Understanding the customer experiences from the perspective of guests and hotel managers: Empirical findings from luxury hotels in Istanbul, Turkey. Journal of Hospitality Marketing \& Management, 25(4), 395-424.

Choi, H. (2010). Religious institutions and ethnic entrepreneurship: The Korean ethnic church as a small business incubator. Economic Development Quarterly, 24(4), 372-383.

Day, N.E., \& Hudson, D. (2011). US small company leaders' religious motivation and otherdirected organizational values. International Journal of Entrepreneurial Behavior \& Research, Vol. 17 Iss 4 pp. $361-379$

Dodd, S.D. \& Seaman P.T. (1998). Religion and Enterprise: An Introductory Exploration. Entrepreneurship Theory and Practice, 3(1), 71-87.

Dyck, B. (2014). God on Management: the world's largest religions, the "theological turn", and organization and management theory and practice, Religion and Organization Theory, 41, 23-62.

Duriez, B., Fontaine, J. R. J., \& Luyten, P. (2001). Does religiosity still influence our lives? New evidence for discriminating value patterns of different types of religiosity. In V.Saroglou \& D.Hutsebaut (Eds.), Religion et développement humain: Questions psychologiques (pp. 93-113). Paris : L'Harmattan.

Elfakhani, S., \& Ahmed, Z.U. (2013). Philosophical basis of entrepreneurship. Principles within an Islamic ethical framework. Journal of Transnational Management, 18, $52-78$.

Essers, C., \& Benschop, Y. (2009). Muslim businesswomen doing boundary work: The negotiation of Islam, gender and ethnicity within entrepreneurial contexts. Human Relations, 62(3), 403-423.

Fernando, M. (2005). Religion's influence on decision-making: evidence of influence on the judgment, emotional and motivational qualities of Sri Lankan leaders' decision-making, 21st European 
Group of Organization Studies (EGOS) Colloquium (pp. 1-17). Berlin, 2005. Germany: Freie Universitat Berlin.

Fontaine, J. R. J., Luyten, P., \& Corveleyn, J. (2000). Tell me what you believe and I'll tell you what you want. Empirical evidence for discriminating value patterns of five types of religiosity. The International Journal for the Psychology of Religion, 10, 65-84.

Gallarza, M. G., Arteaga, F., \& Gil-Saura, I. (2015). Managers' Perceptions of Delivered Value in the Hospitality Industry. Journal of Hospitality Marketing \& Management, 24(8), 857-893.

Graafland,J., Mazereeuw, C., \& Yahia, A. (2006). Islam and socially responsible business conduct: an empirical study of Dutch entrepreneurs. Business Ethics: A European Review, 15(4), 390-406.

Griebel, M., Park, J.Z., \& Neubert, M.J. (2014). Faith and Work: An Exploratory Study of Religious Entrepreneurs, Religions, 5, 780-800; doi: 10.3390/rel5030780

Gümüsay, A.A. (2015). Entrepreneurship from an Islamic Perspectives. Journal of Business Ethics, 130:199-208.

Hill, N., Perkins, S. \& White, J. (2015). The influence of religion on becoming an entrepreneur in the United States. Academy of Entrepreneurship Journal, 21(2), 15-23.

Hoque, N., Mamun, A., \& Mamun, A.M.A. (2013). Dynamics and traits of entrepreneurship: an Islamic approach. World Journal of Entrepreneurship, Management and Sustainable Development, 10(2), 128-142.

Hussan, A. (2016). Islamic ethical responsibilities for business and sustainable development. Humanomics, 32(1), 80-94.

Ismaeel, M. \& Blaim, K. (2012). Toward applied Islamic business ethics: responsible halal business. Journal of Management Development, 31(10), 1090-1100.

Jiang, Y., Ramkissoon, H., \& Mavondo, F. (2016). Destination marketing and visitor experiences: The development of a conceptual framework. Journal of Hospitality Marketing \& Management, 25(6), 653-675.

Jogaratnam, G., Tse, D., \& Olsen, M. D. (1999). An empirical analysis of entrepreneurship and performance in the restaurant industry. Journal of Hospitality and Tourism Research, 23 (4), 339-353.

Kayed, R.N., \& Hassan, K. (2010). Islamic entrepreneurship. London: Routledge.

Keith, G., \& Malcolm, P. (1997). Entrepreneurship in the small hotel sector. International Journal of Contemporary Hospitality Management, 9 (1), 21-25.

Khilji, S.E., Murphy, E.F., Greenwood, R.A. \& Mujtaba, (2014). Plurality within contemporary organizations. Evidence of complexity of value variations and similarities across religions. Cross Cultural Management, 21(2), 219-244.

Kusdil, M. E., \& Kagitcibasi, C. (2000). Value orientations of Turkish teachers and Schwartz's theory of values. Turk Psikoloji Dergisi, 15, 59-80.

Lerner, M., \& Almor, T. (2002). Relationship among strategic capabilities and the performance of women-owned small ventures. Journal of Small Business Management, 40(2), 109-125.

Lui, J., \& Wilson, J.A.J. (2011). The impact of culture and religion on leadership and management training: A comparison of three continents. Journal Pengurusan, 33, 29-36.

McIntosh, J.C. \& Islam, S. (2010). Beyond the veil: the influence of Islam on female entrepreneurship in a conservative Muslim context. International Management Review, 6(1), 2010.

Miller, D. W., \& Timothy, E. (2010). Rethinking the impact of religion on business values: understanding its reemergence and measuring its manifestations. Journal of International Business Ethics, $3(2)$

Noble, A.D., Galbraith, C.S., Singh, G., \& Stiles, C.H. (2007). Market justice, religious orientation, and entrepreneurial attitudes. An empirical study. Journal of Enterprising Communities: People and Places in the Global Economy, 1(2), 121-134.

Nwankwo, S. and Gbadamosi, A. (2013). Faith and entrepreneurship among the British AfricanCaribbean. Intersections between religious and entrepreneurial values. Journal of Small Business and Enterprise Development, 20(3), 618-633.

Nwankwo, S., Gbadamosi, A. and Ojo, S. (2012). Religion, spirituality and entrepreneurship. The church as entrepreneurial space among British Africans. 
Payne, S. (2010). Leadership and spirituality: business in the USA. International Journal of Leadership in Public Services, 6(2), 68 - 72

Pio, E. (2010). Islamic sisters. Spirituality and ethnic entrepreneurship in Sweden. Equality, Diversity and Inclusion: An International Journal, 29 (1), 113-130.

Podgornyi, B.B. (2012). Economic behavior and the influence of religious traditions. Sociological Research, 51(3), 19-37

Reitsma,J., Scheepers, P., \& Grotenhuis, M. (2006). Dimensions of individual religiosity and charity: cross national effect differences in European countries? Review of Religious Research, 47(4), 347362

Roccas, S., Sagiv, L., Schwartz, S., \& Knafo, A. (2002). The big five personality factors and personal values. Personality and Social Psychology Bulletin, 28, 789-801.

Roccas, S., \& Schwartz, S. H. (1997). Church-state relations and the association of religiosity with values: A study of Catholics in six countries. Cross-Cultural Research, 31(4), 356-375.

Roessingh, C. \& Schoonderwoerd, A. (2004). Traditional farmers or modern businessmen? Religious differentiation and entrepreneurship in a Kleine Gemeinde Mennonite community in Belize. Journal of Developmental Entrepreneurship, 10(1), 65-77.

Sabah, S., Carsrud, A.L., \& Kocak, A. (2014). The impact of cultural openness, religion. And nationalism on entrepreneurial intensity: six prototypical cases of Turkish family firms. Journal of Small Business Management, 52(2), 306-324.

Schwartz, S. H., Melech, G., Lehmann, A., Burgess, S., Harris, M., \& Owens, V. (2001). Extending the cross-cultural validity of the theory of basic human values with a different method of measurement. Journal of cross-cultural psychology, 32(5), 519-542.

Schwartz, S. H., \& Huismans, S. (1995). Value priorities and religiosity in four western religions. Social Psychology Quterly, 88-107.

Stephen Payne, (2010),"Leadership and spirituality: business in the USA", International Journal of Leadership in Public Services, Vol. 6 Iss 2 pp. 68 - 72

Vol. 18 Iss 4 pp. $673-694$

Stylos, N., \& Vassiliadis, C. (2015). Differences in Sustainable Management Between Four-and Five-Star Hotels Regarding the Perceptions of Three-Pillar Sustainability. Journal of Hospitality Marketing \& Management, 24(8), 791-825.

Tresidder, R. (2015). Experiences marketing: A cultural philosophy for contemporary hospitality marketing studies. Journal of Hospitality Marketing \& Management, 24(7), 708-726.

Weaver, G.R., \& Agle, B.R. (2002). Religiosity and ethical behavior in organizations: a symbolic interactionist perspective. Academy of Management Review, 27(1), 77-97.

William, E., \& Tse, E. (1995). The relationship between strategy and entrepreneurship; The US restaurant sector. International Journal of Contemporary Hospitality Management, 7 (1), 22-26.

Wong, H.M. (2008). Religiousness, love of money, and ethical attitudes of Malaysian Evangelical Christians in business. Journal of Business Ethics, 81, 169-191.

Woodrum, E. (1985). Religion and economics among Japanese Americans: A Weberian Study. Social Forces, 64(1), 191-204. 
Table 1. Impact of level of commitment to religion on values and entrepreneurship behavior

\begin{tabular}{|c|c|c|c|c|c|}
\hline & & $\begin{array}{l}\text { Practicing } \\
\text { Muslim } \\
\text { entrepreneurs }\end{array}$ & $\begin{array}{c}\text { Non- } \\
\text { practicing } \\
\text { Muslim } \\
\text { entrepreneurs }\end{array}$ & Difference & t-value \\
\hline Values & & $(N=87)$ & $(\mathrm{N}=182)$ & & \\
\hline Conformity & $\begin{array}{l}\mathrm{M} \\
\mathrm{SD} \\
\end{array}$ & $\begin{array}{c}5.36 \\
(1.10) \\
\end{array}$ & $\begin{array}{c}5.28 \\
(1.19) \\
\end{array}$ & 0.08 & 0.54 \\
\hline Tradition & $\begin{array}{l}\mathrm{M} \\
\mathrm{SD}\end{array}$ & $\begin{array}{c}4.90 \\
(1.23) \\
\end{array}$ & $\begin{array}{c}4.26 \\
(1.37) \\
\end{array}$ & 0.64 & $3.73 *$ \\
\hline Benevolence & $\begin{array}{c}M \\
\text { SD }\end{array}$ & $\begin{array}{c}5.78 \\
(0.84)\end{array}$ & $\begin{array}{c}5.64 \\
(0.97)\end{array}$ & 0.16 & 1.30 \\
\hline Universalism & $\begin{array}{c}\mathrm{M} \\
\mathrm{SD}\end{array}$ & $\begin{array}{c}5.52 \\
(0.96)\end{array}$ & $\begin{array}{c}5.42 \\
(0.97)\end{array}$ & 0.10 & 0.78 \\
\hline Self-Direction & $\begin{array}{l}\mathrm{M} \\
\mathrm{SD}\end{array}$ & $\begin{array}{c}5.40 \\
(0.99)\end{array}$ & $\begin{array}{c}5.64 \\
(0.94)\end{array}$ & -0.24 & $-1.97 *$ \\
\hline Stimulation & $\begin{array}{c}\mathrm{M} \\
\mathrm{SD}\end{array}$ & $\begin{array}{c}4.16 \\
(1.74)\end{array}$ & $\begin{array}{c}4.31 \\
(1.51)\end{array}$ & -0.15 & -0.69 \\
\hline Hedonism & $\begin{array}{l}\mathrm{M} \\
\mathrm{SD} \\
\end{array}$ & $\begin{array}{c}4.16 \\
(1.65) \\
\end{array}$ & $\begin{array}{c}4.60 \\
(1.46) \\
\end{array}$ & -0.44 & $-2.07 *$ \\
\hline Achievement & & $\begin{array}{c}5.39 \\
(1.06) \\
\end{array}$ & $\begin{array}{c}5.57 \\
(1.03) \\
\end{array}$ & -0.19 & -1.24 \\
\hline Power & & $\begin{array}{c}4.57 \\
(1.28) \\
\end{array}$ & $\begin{array}{c}4.58 \\
(1.34) \\
\end{array}$ & -0.01 & -0.04 \\
\hline Security & & $\begin{array}{l}6.00 \\
(.85)\end{array}$ & $\begin{array}{l}5.93 \\
(.91)\end{array}$ & 0.07 & 0.63 \\
\hline \multicolumn{6}{|l|}{$\begin{array}{l}\text { Entrepreneurship } \\
\text { behavior }\end{array}$} \\
\hline Risk taking & & $\begin{array}{c}3.72 \\
(0.88) \\
\end{array}$ & $\begin{array}{c}3.79 \\
(0.72) \\
\end{array}$ & -0.07 & -0.59 \\
\hline Competitiveness & & $\begin{array}{c}3.68 \\
(0.71) \\
\end{array}$ & $\begin{array}{c}3.87 \\
(0.69) \\
\end{array}$ & -0.19 & $-2.06^{*}$ \\
\hline Pro-activeness & & $\begin{array}{c}3.83 \\
(0.81) \\
\end{array}$ & $\begin{array}{c}3.76 \\
(0.86) \\
\end{array}$ & 0.07 & 0.59 \\
\hline Innovation & $\begin{array}{l}M \\
\text { SD }\end{array}$ & $\begin{array}{c}5.75 \\
(1.35)\end{array}$ & $\begin{array}{c}5.96 \\
(1.19)\end{array}$ & -0.21 & -1.29 \\
\hline
\end{tabular}

Note: * significant at $\mathrm{p}<0.05$ 
Table 2. Impacts of entrepreneurs' values on their innovation behavior

\begin{tabular}{|c|c|c|c|}
\hline $\begin{array}{l}\text { Model } 1 \text { - } \\
\text { All Muslim Entrepreneurs }\end{array}$ & Coefficient & Std. Error & t-statistics \\
\hline Conformity & $.183^{*}$ & .080 & 2.300 \\
\hline Self-direction & $.725 *$ & .087 & 8.376 \\
\hline R-squared & .415 & & \\
\hline Adjusted R-squared & .392 & & \\
\hline F-statistic & 18.281 & & \\
\hline Prob (F-statistic) & 0.000 & & \\
\hline $\begin{array}{l}\text { Model } 2 \text { - } \\
\text { Practicing Muslim entrepreneurs }\end{array}$ & Coefficient & Std. Error & t-statistics \\
\hline Self-direction & $.714 *$ & .177 & 4.047 \\
\hline R-squared & .419 & & \\
\hline Adjusted R-squared & .343 & & \\
\hline F-statistic & 5.484 & & \\
\hline Prob (F-statistic) & 0.000 & & \\
\hline $\begin{array}{l}\text { Model } 3 \text { - } \\
\text { Non-practicing Muslim entrepreneurs }\end{array}$ & Coefficient & Std. Error & t-statistics \\
\hline Conformity & $.207^{*}$ & .092 & 2.247 \\
\hline Self-direction & $.702 *$ & .101 & 6.923 \\
\hline Achievement & $.195 *$ & .097 & 2.007 \\
\hline R-squared & .438 & & \\
\hline Adjusted R-squared & .405 & & \\
\hline F-statistic & 13.327 & & \\
\hline Prob (F-statistic) & 0.000 & & \\
\hline
\end{tabular}

Note: * significant at $\mathrm{p}<0.05$ 
Table 3. Impacts of entrepreneurs' values on their risk taking behavior

\begin{tabular}{|c|c|c|c|}
\hline $\begin{array}{l}\text { Model } 1 \text { - } \\
\text { All Muslim Entrepreneurs }\end{array}$ & Coefficient & Std. Error & t-statistics \\
\hline Benevolence & $.180 *$ & .081 & 2.236 \\
\hline Stimulation & $.133^{*}$ & .039 & 3.461 \\
\hline Power & $-.184 *$ & .050 & -3.690 \\
\hline R-squared & 0.192 & & \\
\hline Adjusted R-squared & 0.159 & & \\
\hline F-statistic & 5.972 & & \\
\hline Prob (F-statistic) & 0.00 & & \\
\hline $\begin{array}{l}\text { Model } 2 \text { - } \\
\text { Practicing Muslim entrepreneurs }\end{array}$ & Coefficient & Std. Error & t-statistics \\
\hline Power & $-.207 *$ & .103 & -2.003 \\
\hline R-squared & 0.214 & & \\
\hline Adjusted R-squared & .107 & & \\
\hline F-statistic & 2.011 & & \\
\hline Prob (F-statistic) & 0.044 & & \\
\hline $\begin{array}{l}\text { Model } 3 \text { - } \\
\text { Non- practicing Muslim entrepreneurs }\end{array}$ & Coefficient & Std. Error & t-statistics \\
\hline Tradition & $-.140^{*}$ & .056 & -2.482 \\
\hline Benevolence & $.268^{*}$ & .094 & 2.844 \\
\hline Stimulation & $.153^{*}$ & .050 & 3.055 \\
\hline R-squared & .221 & & \\
\hline Adjusted R-squared & .174 & & \\
\hline F-statistic & 4.725 & & \\
\hline Prob (F-statistic) & 0.000 & & \\
\hline
\end{tabular}

Note: * significant at $\mathrm{p}<0.05$ 
Table 4. Impacts of entrepreneurs' values and their competitiveness behavior

\begin{tabular}{|c|c|c|c|}
\hline $\begin{array}{l}\text { Model } 1 \text { - } \\
\text { All Muslim Entrepreneurs }\end{array}$ & Coefficient & Std. Error & t-statistics \\
\hline Self-direction & $.166^{*}$ & .059 & 2.825 \\
\hline Achievement & $.194 *$ & .055 & 3.498 \\
\hline Power & $-.089 *$ & .042 & -2.132 \\
\hline R-squared & 0.160 & & \\
\hline Adjusted R-squared & 0.126 & & \\
\hline F-statistic & 4.783 & & \\
\hline Prob (F-statistic) & 0.00 & & \\
\hline $\begin{array}{l}\text { Model } 2 \text { - } \\
\text { Practicing Muslim entrepreneurs }\end{array}$ & Coefficient & Std. Error & t-statistics \\
\hline Universalism & $.316^{*}$ & .125 & 2.538 \\
\hline Self-direction & $.258 *$ & .102 & 2.524 \\
\hline Security & $-.270 *$ & .133 & -2.026 \\
\hline R-squared & 0.314 & & \\
\hline Adjusted R-squared & 0.22 & & \\
\hline F-statistic & 3.341 & & \\
\hline Prob (F-statistic) & 0.00 & & \\
\hline $\begin{array}{l}\text { Model } 3 \text { - } \\
\text { Non- practicing Muslim entrepreneurs }\end{array}$ & Coefficient & Std. Error & t-statistics \\
\hline Achievement & $.175^{*}$ & .069 & 2.538 \\
\hline Power & $-.110 *$ & .049 & -2.240 \\
\hline R-squared & 0.154 & & \\
\hline Adjusted R-squared & 0.103 & & \\
\hline F-statistic & 3.047 & & \\
\hline Prob (F-statistic) & 0.0001 & & \\
\hline
\end{tabular}

Note: * significant at $\mathrm{p}<0.05$ 